\title{
Combined methods for the treatment of a typical hardwood soaking basin wastewater from plywood industry
}

\author{
D. Klauson · K. Klein • A. Kivi • E. Kattel • \\ M. Viisimaa $\cdot$ N. Dulova $\cdot$ S. Velling $\cdot$ \\ M. Trapido $\cdot$ T. Tenno
}

Received: 10 July 2014/Revised: 13 January 2015/ Accepted: 14 February 2015/Published online: 24 February 2015

(C) Islamic Azad University (IAU) 2015

\begin{abstract}
In this research, various combinations of physicochemical (coagulation, Fenton process and ozonation) and biological (aerobic oxidation) treatment methods were used to purify wastewater originating from wood soaking basins in plywood production industry. Although the wastewater has good biodegradability $(92 \%)$, there is a high fraction of organic material expressed as recalcitrant chemical oxygen demand (COD) of approximately $360 \mathrm{mg} \mathrm{L}^{-1}$. High fraction of organics is caused by woodoriginating water-soluble material, i.e. extractives, including lignin and tannins. It was found that optimal treatment method for hardwood soaking basin wastewater is the combination of biological pre-treatment, chemical treatment with Fenton reagent and biological post-treatment. Under optimal conditions of combined process performance, up to $99 \%$ removal of the organic loads, nitrogen and phenols was achieved. Besides achieving target discharge limits stated for industrial wastewater, the effluent met the requirements set for municipal wastewater treatment plants, making the treated water acceptable for subsequent discharge into natural water bodies: treated water $\mathrm{COD}=90 \pm 3 \mathrm{mg} \mathrm{L}^{-1} ; \mathrm{BOD}_{7}=10 \pm 1 \mathrm{mg} \mathrm{L}^{-1}$. The main result of the present work was the establishment of sustainable, efficient and economically feasible process to treat the wastewater with minimised chemicals consumption. This differs considerably from approaches such as
\end{abstract}

D. Klauson $(\bowtie) \cdot$ E. Kattel $\cdot$ M. Viisimaa $\cdot$ N. Dulova M. Trapido

Department of Chemical Engineering, Tallinn University of

Technology, Ehitajate tee 5, 19086 Tallinn, Estonia

e-mail: deniss.klauson@ttu.ee

K. Klein · A. Kivi $\cdot$ S. Velling $\cdot$ T. Tenno Department of Chemistry, University of Tartu, Ravila 14a, 50411 Tartu, Estonia coagulation or wet oxidation, used to treat similar water types according to the literature, and is readily applicable for the production facilities of various scales, including small and medium enterprises, without the need to make changes in existing technological schemes.

Keywords Wood processing wastewater. Physicochemical treatment - Biological oxidation . Multistage wastewater treatment

\section{Introduction}

Plywood is a widely used wood-based product; its manufacturing is an important part of woodworking industry: in 2011, it was estimated to be around 81 million $\mathrm{m}^{3}$ worldwide, with a market value of around $\$$ 19 billion (Fernández et al. 2012).

One of the plywood production stages is wood soaking, often carried out at elevated temperatures in order to increase the plastic properties of wood before debarking and veneer cutting. This results in a solution containing lignin, water-soluble wood and bark matter, i.e. extractives, and certain amount of mechanical particles. The extractives are a range of organics with diverse functions and structure, such as terpenes, resin acids, triglycerides, fatty acids, phenolic compounds, among others; their relative abundance depends on the type of wood. As one of the functions of extractives is the protection of trees from pathogens, they possess at least certain degree of toxicity, which is transferred to respective soaking water; even at low concentrations, wood extractives have been reported to produce wastewater with pronounced toxicological and hormonal effects (Lehtinen et al. 1999). The brownish colour of the wastewater originated from wood industry is 
mainly attributed to lignin and its derivates, which are resistant to microbial degradation, and can also cause toxic and hormonal effects in aquatic environments at very low concentrations (Leiviskä et al. 2009). Available ecotoxicological tests have shown that the presence of tannin and lignin in wastewater leads to decrease in respiration rate of activated sludge, having also toxic effect according to Daphnia magna test (Libralato et al. 2011). Moreover, some of the extractives, e.g. lignin, can effectively adsorb other pollutants in the wastewater, including micropollutants (Han et al. 2012) and heavy metals (Singh and Prasad 2015); on the other hand, lignin is resistant to many conventionally employed treatment techniques (Leiviskä et al. 2009; Portjanskaja et al. 2009), thus serving as various pollutants' transportation and protection medium in case of wood industry wastewater, either untreated or incompletely treated, mixed with municipal wastewater. Thus, both freshwater and sea water communities could be affected by discharges containing tannin and lignin.

In order to minimise the freshwater consumption in the soaking process and make it more environmentally friendly, water is used multiple times. This decreases the consumption of freshwater, increasing the amount of extractives present in the soaking basin, which results in the formation of wastewater that needs to be dealt with efficiently, requiring advanced technological solutions.

In contrast with the order of magnitude of plywood production, the literature data on the treatment possibilities of soaking basin water are scarce. Moreover, the proposed solutions are somewhat ambiguous: e.g. while partial closure of the water cycle with $2 / 3$ of the initial water amount recycled, with air flotation, coagulation by aluminium sulphate was reported to result in $57 \%$ removal of the chemical oxygen demand (COD) and $50 \%$ of 7-day biochemical oxygen demand $\left(\mathrm{BOD}_{7}\right)$ (Jokela and Keskitalo 1999); this results in the creation of solid waste that needs to be treated. On the one hand, such waste inevitably contains significant amounts of water and requires subsequent dewatering in order to reduce its volume for further disposal, and on the other hand, it is laden with surfaceadsorbed extractives, which make it a concentrated hazardous waste. In case of somewhat similar water samples from wet debarking process, biological treatment was reported to result in ca. $70 \%$ COD removal without significantly affecting colour, attributed to lignin (Leiviskä et al. 2008); while a high percentage of the extractives can be removed biologically (Kostamo and Kukkonen 2003; Leiviskä et al. 2009), even diluted effluents possess substantial toxicity, not to mention the possible breakthroughs of toxic influent during the periods of unstable operation of biological process. There has also been reported a possible increase in some of the remaining extractive compounds toxicity due to chemical transformations during biological treatment (Stahlschmidt-Allner et al. 1997). Adsorption and coagulation of wet debarking process of wastewater resulted in the removal of up to $91 \%$ of the lipophilic extractives from the treated wastewater (Leiviska et al. 2012); however, this technology has similar drawbacks as described in case of coagulation. Wet oxidation (WO) of a more concentrated debarking water samples resulted in up to $98 \%$ lignin removal, while the removal of COD was about $61 \%$ (Kindsigo and Kallas 2009). However, technological solutions, such as water cycle closure or WO implementation, are easier to apply at larger-scale production facilities, as opposed to numerous smaller-scale productions. This further implies to the need for alternative easily applicable sustainable technology to treat the wood soaking basin water efficiently both in terms of results and costs.

A set of technologies commonly referred to as advanced oxidation processes (AOPs), including Fenton oxidation, have shown efficient performance in eliminating pollutants of various structure and properties (Wang and Xu 2012), though the action of individual AOPs against certain pollutant classes is selective (Malato et al. 2007; Mantzavinos and Psillakis 2004). Some publications, e.g. Vlyssides et al. (2008) and Munoz et al. (2014), have considered applying Fenton process to wood industry-connected wastewaters, achieving significant pollutant load reduction, although the results provided by the AOPs, unless the latter are optimised, may be obtained at the cost of high reagent and energy consumption. With optimisation undertaken, the AOPs alone can be relatively efficient at least in part of the cases: e.g. in the work of Munoz et al. (2014), Fenton treatment of a medium-strength sawmill wastewater (COD of ca. $3000 \mathrm{mg} \mathrm{L}^{-1}$ ) at elevated temperature and with $\mathrm{H}_{2} \mathrm{O}_{2}$ addition in several doses (as opposed to single addition) resulted in up to $80 \%$ COD removal at the treatment cost of 3.19 eur $\mathrm{m}^{-3}$. While providing relatively efficient performance at moderate pollutant loads, this also suggests that in case of more concentrated effluents and higher demands for COD removal, the final cost of applying AOPs may increase significantly. While AOPs have the potential to oxidise the majority of organic pollutants, quantities of chemical doses employed in these processes need to be considered; dosages determine, to a large extent, the operating cost, efficiency and sustainability of the treatment. On the other hand, conventional treatment methods like biological processes have proved to be sustainable, relatively cheap and efficient methods when operating at optimal and uniform set of conditions, including loads, feed amount and influent toxicity. However, in certain cases like industrial effluents, they are not always effective, mainly due to toxic and persistent pollutants in the wastewater (Reemtsma et al. 1999; Ren 2004) and hydraulic and organic shock loads created by peak volumes 
and concentrations (Pophali et al. 2003; Seetha et al. 2010). Consequently, an advanced system combined of individual physicochemical and biological treatment stages would be the solution for obtaining optimal conditions to treat wood soaking water efficiently both in terms of performance and cost. While such combined treatment processes were investigated for various water types, e.g. landfill leachate (Klauson et al. 2014), textile yarn dyeing effluent (Lotito et al. 2014), the authors could not find any such publications for wood industry-based wastewaters.

In this research, the authors used Fenton process, coagulation and ozonation as chemical (physicochemical) treatment technologies and activated sludge process as a biological treatment technique. As the research was conducted in Northern Europe, geographic latitude-derived factors pose their limitations: the option of using highly efficient solar light-driven photo-Fenton process could not be given much attention as it would have been a working option for only a part of summer. In order to increase the efficiency of the process as much as possible, it is necessary to determine the optimal operational $\mathrm{H}_{2} \mathrm{O}_{2} / \mathrm{Fe}^{2+}$ molar ratio. At the same time, the results of authors' previous studies (Kulik et al. 2008; Dulova and Trapido 2011) suggest that the $\mathrm{H}_{2} \mathrm{O}_{2} / \mathrm{Fe}^{2+}$ ratio of $10 / 1$ $(\mathrm{mol} / \mathrm{mol})$ provides the best performance of Fenton's reagent for wastewater treatment. Based on this knowledge, by adjusting the $\mathrm{COD} / \mathrm{H}_{2} \mathrm{O}_{2}$ ratio, it is possible to obtain the highest treatment results coupled with decreased reagent consumption. The combination of the adjusted Fenton treatment with biological oxidation can increase the efficiency of chemicals use and thus decreases process costs: e.g. biological pretreatment decreases the chemical consumption by removing the easily degradable organics, leaving solely the recalcitrant part of COD for chemical treatment; the goal of the latter, however, is not the complete pollutant mineralisation, but producing biodegradable fragments instead.

Chemical and biological treatment technologies were evaluated and adjusted separately and then combined in different sequences. The following combined treatment schemes were examined:

- Coagulation

- Fenton treatment

- Coagulation-Fenton treatment

- Coagulation-ozonation

- Activated sludge process-Fenton treatment (BIOCHEM)

- Activated sludge process-Fenton treatment-activated sludge process (BIO-CHEM-BIO)

The goal and the major novelty of the current study is the establishing of a readily applicable, sustainable, efficient and economically feasible combined treatment technology for the treatment of wood soaking basin wastewater. An optimal treatment scheme is established by taking into account both the performance and material consumption minimisation.

The research presented in this manuscript was carried out in spring 2013 to spring 2014 in Tallinn University of Technology (Tallinn, Estonia) and University of Tartu (Tartu, Estonia).

\section{Materials and methods}

Analytical methods

Standard colorimetric method (APHA 2012) was used in order to determine the chemical oxygen demand (COD) of the wastewater; the interference of hydrogen peroxide was estimated as described previously (Klauson et al. 2014). The 7-day biochemical oxygen demand $\left(\mathrm{BOD}_{7}\right)$ was determined in the initial and treated wastewater samples according to the standard procedure (APHA 2012). The acute toxicity was tested using $D$. magna 24 -h test, according to ISO 6341:2012 standard (ISO 2012). The $\mathrm{pH}$ measurements were taken using a Schott $840 \mathrm{pH}$-meter, and the electrical conductivity measurements using HANNA Instruments HI9032 EC meter. Total and ferrous iron was determined by the standard phenanthroline method (APHA 2012). Hydrogen peroxide concentration in stock solutions was measured spectrophotometrically at $\lambda=254 \mathrm{~nm}$, and residual hydrogen peroxide in the treated samples was measured as described in Bolobajev et al. (2014) by Thermo Electron He $\lambda$ ios- $\beta$ UV/Vis. The concentrations of anions $\left(\mathrm{F}^{-}, \mathrm{Cl}^{-}, \mathrm{NO}_{3}{ }^{-}, \mathrm{SO}_{4}{ }^{2-}, \mathrm{PO}_{4}{ }^{-}\right)$ were measured by ion chromatography with chemical suppression of eluent conductivity using Metrohm 761 Compact IC. Dissolved organic carbon (DOC) and dissolved nitrogen (DN) were measured in pre-filtered samples $\left(0.45 \mu \mathrm{m}\right.$, Whatman $\left.{ }^{\mathrm{TM}}\right)$ by Analytik Jena Multi N/C 3100 analyser, and total organic carbon (TOC) was measured in unfiltered samples by HACH-Lange cuvette test according to EN 1484 (ECS 1997). Additionally, total nitrogen (TN) in unfiltered samples was measured with peroxodisulphate method (ISO 2003). $\mathrm{NH}_{4}-\mathrm{N}$ was determined by spectrophotometric method with Nessler reagent adapted from (APHA 2012), or in case of low concentrations, according to ISO 7150-1 (ISO 1984), and $\mathrm{NO}_{3}-\mathrm{N}$ according to ISO 7890-3 (ISO 1988). Total solids were measured gravimetrically according to (APHA 2012). The concentration of lignin and tannins was measured spectrophotometrically by tyrosine method using HACH-Lange cuvette test (APHA 2012). The 
concentration of phenols was measured by sodium nitrite method using HACH-Lange cuvette test (APHA 2012). Values are expressed as average with standard deviations of at least three samples.

\section{Wastewater sample characterisation}

Samples were taken from hardwood soaking basin of the local plywood industry. The enterprise has a soaking basin with the volume of $800 \mathrm{~m}^{3}$, with water changing yearly. During separate samplings at different times of the year, wastewater characteristics varied considerably. The composition of plywood industry wastewater depends on its retention time in soaking basin; water with longer retention time is more concentrated. The samples are referred to $S 1$, $\mathrm{S} 2$ and S3, which were taken 8 months apart. The collected wastewater was stored at $4{ }^{\circ} \mathrm{C}$.

Table 1 shows the composition of wood soaking basin wastewater samples. The wastewater has moderate organic loads between ca. 5000 and $8000 \mathrm{mg} \mathrm{L}^{-1} \mathrm{COD}$, with biodegradability, expressed as $\mathrm{BOD}_{7} / \mathrm{COD}$ ratio varying between 0.2 and 0.5 . At the same time, $\mathrm{pH}$ and TSS change little. Wastewater contains high concentration of total suspended solids; almost $50 \%$ of COD is not dissolved (S3). Additionally, significant difference in the concentration of total and dissolved nitrogen was observed (S1). Besides organics, nitrogen, phosphorus and phenols need to be removed from the wastewater; their concentrations may vary significantly in case of various samples. This can be explained by the differences in wood amounts soaked in the water, the composition of the soaked wood, i.e. relative abundance of different wood species, periodic additions of freshwater to compensate evaporation losses and residence time.

\section{Chemical treatment}

Fenton treatment was performed in cylindrical batch glass reactor under constant stirring (400 rpm) with magnetic stirrer. Upon the addition and complete dissolution of ferrous sulphate $\left(\mathrm{FeSO}_{4} \cdot 7 \mathrm{H}_{2} \mathrm{O}\right)$, hydrogen peroxide was added either once or stepwise (after $0,30,60 \mathrm{~min}$ of oxidation) to initiate the reaction. Concentrations of $\mathrm{H}_{2} \mathrm{O}_{2}$ and $\mathrm{Fe}^{2+}$ were always calculated according to $\mathrm{COD}$ value $\left(\mathrm{COD} / \mathrm{H}_{2} \mathrm{O}_{2} / \mathrm{Fe}^{2+} \mathrm{w} / \mathrm{w} / \mathrm{w}\right)$. The sample $\mathrm{pH}$ was not adjusted, unless stated otherwise. In general, a fast decrease in the reaction mixture's $\mathrm{pH}$ to values lower than 3 was observed. The reason to this decrease is mainly the acidity
Table 1 Chemical composition and properties of wood soaking basin wastewater samples

\begin{tabular}{|c|c|c|c|c|}
\hline \multirow[t]{2}{*}{ Parameter } & \multirow[t]{2}{*}{ Unit } & \multicolumn{3}{|l|}{ Value } \\
\hline & & S1 & S2 & S3 \\
\hline COD & $\mathrm{mg} \mathrm{L}^{-1}$ & $5150 \pm 210$ & $7860 \pm 90$ & $6834 \pm 250$ \\
\hline $\begin{array}{l}\text { COD (filtered } \\
\text { sample, } \\
0.45 \mu \mathrm{m} \text { ) }\end{array}$ & $\mathrm{mg} \mathrm{L}^{-1}$ & n.a. & n.a. & $3454 \pm 90$ \\
\hline $\mathrm{BOD}_{7}$ & $\mathrm{mg} \mathrm{L}^{-1}$ & $1610 \pm 130$ & $1600 \pm 120$ & $3533 \pm 275$ \\
\hline $\mathrm{BOD}_{7} / \mathrm{COD}$ & - & 0.31 & 0.20 & 0.51 \\
\hline DOC & $\mathrm{mg} \mathrm{L}^{-1}$ & $975 \pm 2$ & $680 \pm 2$ & $585 \pm 5$ \\
\hline TOC & $\mathrm{mg} \mathrm{L}^{-1}$ & 3240 & 2795 & 1570 \\
\hline Conductivity & $\mu \mathrm{S} \mathrm{cm}-1$ & 970 & n.a. & n.a. \\
\hline $\mathrm{pH}$ & - & $4.75 \pm 0.01$ & $4.8 \pm 0.01$ & $5.05 \pm 0.01$ \\
\hline $\begin{array}{l}\text { Total solids } \\
\left(105^{\circ} \mathrm{C}\right)\end{array}$ & $\mathrm{mg} \mathrm{L}^{-1}$ & $2550 \pm 30$ & n.a & n.a. \\
\hline $\begin{array}{l}\text { Fixed solids } \\
\left(600^{\circ} \mathrm{C}\right)\end{array}$ & $\mathrm{mg} \mathrm{L}^{-1}$ & $520 \pm 6$ & n.a. & n.a. \\
\hline $\begin{array}{l}\text { Total } \\
\quad \text { suspended } \\
\text { solids } \\
\left(105^{\circ} \mathrm{C}\right)\end{array}$ & $\mathrm{mg} \mathrm{L}^{-1}$ & $1800 \pm 80$ & n.a. & $1780 \pm 60$ \\
\hline $\mathrm{TN}$ & $\mathrm{mg} \mathrm{L}^{-1}$ & $11.2 \pm 0.3$ & n.a. & $69.3 \pm 3.5$ \\
\hline DN & $\mathrm{mg} \mathrm{L}^{-1}$ & $4.9 \pm 1.3$ & $1.7 \pm 0.6$ & n.a. \\
\hline $\mathrm{NH}_{4}-\mathrm{N}$ & $\mathrm{mg} \mathrm{L}^{-1}$ & 1.7 & n.a. & $50 \pm 0.8$ \\
\hline $\mathrm{F}^{-}$ & $\mathrm{mg} \mathrm{L}^{-1}$ & $60 \pm 3$ & n.a. & $<$ l.d \\
\hline $\mathrm{Cl}^{-}$ & $\mathrm{mg} \mathrm{L}^{-1}$ & $560 \pm 5$ & n.a. & 36.8 \\
\hline $\mathrm{TP}$ & $\mathrm{mg} \mathrm{L}^{-1}$ & n.a. & n.a. & 37.5 \\
\hline $\mathrm{PO}_{4}{ }^{3-}$ & $\mathrm{mg} \mathrm{L}^{-1}$ & $66 \pm 2$ & n.a. & $33 \pm 0.8$ \\
\hline $\mathrm{SO}_{4}{ }^{2-}$ & $\mathrm{mg} \mathrm{L}^{-1}$ & $161 \pm 4$ & n.a. & $<$ l.d. \\
\hline Phenols & $\mathrm{mg} \mathrm{L}^{-1}$ & $51.1 \pm 5$ & n.a. & $94 \pm 6$ \\
\hline $\begin{array}{l}\text { D. magna } \\
\text { acute } \\
\text { toxicity } \\
\text { IC }_{50}\end{array}$ & $\%$ & $15.3 \pm 2.2$ & $9.3 \pm 1.6$ & n.a. \\
\hline $\begin{array}{l}\text { Lignin and } \\
\text { tannins }\end{array}$ & $\mathrm{mg} \mathrm{L}^{-1}$ & $560 \pm 10$ & $870 \pm 42$ & n.a. \\
\hline
\end{tabular}

n.a. not analysed

$<$ l.d. below limit of detection

of added iron catalyst and hydrogen peroxide and the acidic by-products formation. The treatment time was $24 \mathrm{~h}$. The oxidation was stopped by addition of $\mathrm{NaOH}(10 \mathrm{M})$ to adjust $\mathrm{pH}$ to approximately 9 . The $\mathrm{pH}$ regulation was followed by ferric hydroxy complexes settling period of $24 \mathrm{~h}$; the supernatant was collected for further analysis.

In the ozonation experiments, $600 \mathrm{~mL}$ of wood soaking basin wastewater was treated in 2.6-L semi-continuous 
reactor equipped with foam-catching vessel. Ozone was produced from compressed air in Trailigaz LABO LO ozone generator, delivering $1.0 \mathrm{~L} \mathrm{~min}^{-1}$ feed gas with ozone concentrations ranging from 10 to $40 \mathrm{mg} \mathrm{L}^{-1}$. Anseros GM 6000-PRO ozone analyser was used to measure the ozone concentration in gaseous phase. The $\mathrm{pH}$ was not adjusted. The treatment time was $2 \mathrm{~h}$.

The coagulation with ferric sulphate (KEMIRA PIX$322, \mathrm{Fe}_{\text {total }} 12.5 \pm 0.3 \%$ ) was performed in a jar test apparatus (Kemira, Finland). The wastewater volume in each jar was $0.6 \mathrm{~L}$. The coagulant doses $\left(\mathrm{Fe}_{\text {total }}\right)$ varied in the range of $100-1000 \mathrm{mg} \mathrm{L}^{-1}$. The operating conditions were as follows: $1 \mathrm{~min}$ of fast mixing at $400 \mathrm{rpm}, 30 \mathrm{~min}$ of slow mixing at $40 \mathrm{rpm}$ and $24 \mathrm{~h}$ of sedimentation.

\section{Characterisation of biodegradability and toxicity}

Biodegradability of wood soaking basin wastewater samples (raw and treated) was determined using Zahn-Wellens test (ISO 1999). The activated sludge used in this test originated from a municipal wastewater treatment plant (WWTP) in Tartu, Estonia. In addition to biodegradability based on the COD removal curve, the sample was also fractionated, dividing it into three parts: easily biodegradable COD (degrades during first 7 days), slowly biodegradable COD (degrades in 7-28 days), and recalcitrant COD, i.e. the residual COD in the test.

The inhibition of oxygen uptake rate and nitrification rate by activated sludge was performed according to ISO 8192 and ISO 9509, respectively (ISO 2006, 2007). Activated sludge used in inhibition tests originated from the same WWTP.

Set-up of the biological treatment

Aerobic biological pre-treatment experiments were performed in 1-L batch reactors, with HRT of $5 \mathrm{~h}$ and MLSS concentration of around $2 \mathrm{~g} \mathrm{~L}^{-1}$. Before start-up, the activated sludge was adapted with treated wastewater for $2 \mathrm{~h}$ (10\% wastewater and $90 \%$ activated sludge).

Aerobic biological post-treatment experiments were carried out at laboratory scale for two weeks employing a typical plug-flow activated sludge set-up. The treatment system consisted of aeration tank $(4.8 \mathrm{~L})$ followed by a clarifier $(1.5 \mathrm{~L})$. The aeration tank was colonised by activated sludge, obtained from the above-mentioned WWTP. Aeration was performed by air pump and diffuser installed at the bottom of the tank. The $\mathrm{pH}$ was regulated to $7.5 \pm 0.1$ to ensure bacterial activity in activated sludge. Wastewater was fed to the aeration tank by a peristaltic pump with adjusted flow rate of approximately $0.07 \mathrm{~L} \mathrm{~h}^{-1}$. Mixed liquid suspended solids concentration (MLSS) was kept 5.5-7 $\mathrm{g} \mathrm{L}^{-1}$. Hence, the system operated at hydraulic retention time (HRT) of 3 days and high-rated sludge loading (0.17-0.21 $\mathrm{g} \quad \mathrm{BOD}_{7}$ day $^{-1}$ per $1 \mathrm{~g}$ MLSS); relatively high HRT is not exceptional when wastewater with relatively high pollutant loads is to be treated.

Two types of biological reactors were applied in this study, as biological pre-treatment was performed adapting longer hydraulic retention time, due to high organic load. In case of adapting the same hydraulic retention time for biological post-treatment, the reactor would have been strongly underloaded.

During the operating periods, MLSS in the aeration basin and COD in the effluent were measured daily. The effluent was kept in a refrigerator at $4{ }^{\circ} \mathrm{C}$ to avoid further decomposition.

Evaluation of reagent consumption

The evaluation of reagent consumption for Fenton process was undertaken by calculating the use of chemicals per $1 \mathrm{~m}^{3}$ of the wastewater, taking into account the respective COD values and $\mathrm{COD} / \mathrm{H}_{2} \mathrm{O}_{2} / \mathrm{Fe}^{2+}$ w/w/w ratios. Reagent consumption was presented as $\mathrm{kg}$ of ferric sulphate (FeS$\mathrm{O}_{4} \cdot 7 \mathrm{H}_{2} \mathrm{O}$ ) and $\mathrm{L}$ of $50 \% \mathrm{H}_{2} \mathrm{O}_{2}$ per $1 \mathrm{~m}^{3}$ of treated water. As the reagent costs, especially that of $\mathrm{H}_{2} \mathrm{O}_{2}$, being the bulk of reagent costs in Fenton process, depend on many factors, such as location, quantities to be acquired, operational cost analysis for the specific local case was performed to provide a cost-based comparison, using the same methodologies as previously applied by the authors (Munter et al. 2006; Krichevskaya et al. 2011), with prices corrected to meet the current situation. For this, the following prerequisites were used: wastewater production of $800 \mathrm{~m}^{3}$ year $^{-1}$, with hydrogen peroxide $\left(50 \%\right.$ solution) and $\mathrm{FeSO}_{4} \cdot 7 \mathrm{H}_{2} \mathrm{O}$ costs corresponding to that wastewater amount estimated as 1000 and 350 eur t $^{-1}$ (Algol Chemicals OÜ 2014). The cost of coagulant was 285 eur t $^{-1}$ (Kemira 2014). Energy consumption for ozone generation and use was estimated as $36 \mathrm{MJ} \mathrm{kg}^{-1} \mathrm{O}_{3}$ (ca. $10 \mathrm{~kW} \mathrm{~h} \mathrm{~kg}{ }^{-1} \mathrm{O}_{3}$ ) based on the available literature data (Papa et al. 2013), with the corresponding energy costs for business customers of 0.0588 eur $(\mathrm{kW} \mathrm{h})^{-1}$ (Eesti Energia 2014). Energy consumption in Fenton process was not taken into consideration, as it would comprise primarily of dosage pumps working for short periods of time and mechanical stirrer for the preparation of ferrous sulphate solutions; both would be small and highly dependent on the exact equipment used. As for the biological part of the treatment process, it has been reported (Villano et al. 2013) that between 0.8 and $1.0 \mathrm{~kW}$ h (average 0.9 ) of energy is consumed for aeration in order to remove $1 \mathrm{~kg}$ of COD, while this makes up a total of 40-65\% (average ca. $53 \%$ ) of the total energy consumption in the activated sludge process (Fernández et al. 2011; Liu et al. 2011); thus, $1.7 \mathrm{~kW} \mathrm{~h}$ of energy is consumed per 
$1 \mathrm{~kg}$ of COD removed in the aerobic treatment stage. However, taking into account the relatively limited value of such an analysis, the authors suggest that the amount of consumed reagents would provide a more objective comparison of the analysed processes' performance, while serving as the base for costs calculation by interested parties depending on any given application.

\section{Results and discussion}

Toxicity and biodegradability of raw wastewater

In order to assess the effect of wastewater on the activated sludge, oxygen demand and nitrification inhibition tests were carried out (Sample S1, S2). Figure 1, presenting the results obtained with sample $\mathrm{S} 1$, shows that raw hardwood soaking basin wastewater has modest inhibitory effect on activated sludge: $25.5 \%$ of raw wastewater results in $50 \%$ decrease in oxygen demand and $17 \%$ of raw wastewater results in $50 \%$ decrease in nitrification rate; additionally, the inhibitory effect did not vary in different samples. Consequently, it is possible to perform direct aerobic biotreatment with longer hydraulic retention time and higher sludge age (Wang et al. 2013).

In order to assess the biodegradability and predict potential efficiency of biological pre-treatment, Zahn-Wellens test was performed (sample S2), lasting up to 28 days. It was observed that plywood industry wastewater has high biodegradability (93\%). When evaluating the degradation curve of the wastewater, $83 \%$ of COD decreased in 7 days and $9 \%$ in the period of 7-28 days, which indicate easily and slowly biodegradable fraction, respectively. Although the biodegradability is high, $7 \%$ of COD $\left(360 \mathrm{mg} \mathrm{L}^{-1}\right)$ was not removed during 28 days. In case of biological pre-treatment, the effluent would be too concentrated for discharge into water bodies, demanding further treatment.

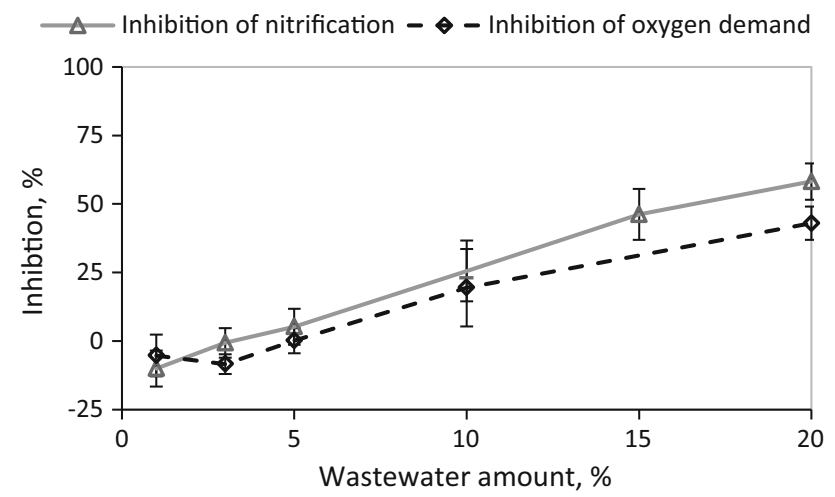

Fig. 1 Test results of inhibition tests of nitrification rate and oxygen demand by raw wastewater (sample S1 and S2)
Chemical treatment of wastewater

\section{Coagulation}

The results of coagulation experiments (sample S1) suggest $200 \mathrm{mg} \mathrm{L}^{-1}$ of $\mathrm{Fe}_{\text {total }}$ as an optimal PIX-322 dose; the addition of flocculant (Zetag 4105) provided insignificantly small improvement in treatment efficiency and was not used in the subsequent experiments. The results of wood soaking basin water coagulation obtained with samples S1 and $\mathrm{S} 2$ at $200 \mathrm{mg} \mathrm{L}^{-1}$ of $\mathrm{Fe}_{\text {total }}$ are shown in Table 2. It can be seen that coagulation provides more than 35 and $30 \%$ of COD and DOC removal, respectively. That should be mainly associated with decreased content of suspended solids, obtained by coagulation. At the same time, coagulation was shown to eliminate up to $86 \%$ of lignin and tannins (S2). While the changes in $\mathrm{BOD}_{7} / \mathrm{COD}$ ratio were different in case of different samples, originating from different $\mathrm{BOD}_{7}$ and similar $\mathrm{COD}$ removal rates, a significant improvement in the acute toxicity was observed: it decreased about three times with both S1 and S2. According to inhibition tests, coagulation had no effect on activated sludge nitrification rate and oxygen demand. Consequently, the coagulation can be an option for the first step of chemical pre-treatment process.

\section{Ozonation}

Sample S1 was treated by ozonation and a combination of coagulation and ozonation. Ozonation without preceding coagulation allowed the removal of around 35-37 \% COD at both unregulated and alkaline $\mathrm{pH}$, whereas the removal of $\mathrm{BOD}_{7}$ under these conditions was 12 and $68 \%$, respectively. Air stripping was able to remove about $16 \%$ of the initial $\mathrm{COD}$ and $10 \%$ of $\mathrm{BOD}_{7}$, suggesting that chemical degradation is mainly responsible for the observed purification effect in case of ozonation. The results of ozonation experiments $\left(30 \mathrm{mg} \mathrm{O} \mathrm{L}^{-1}\right)$ of pre-coagulated water (S1) at unregulated $\mathrm{pH}$ are provided in Table 2: these suggest that ozonation preceded by coagulation is more efficient; however, the performance of ozonation was still inferior to that of Fenton treatment in all terms except acute toxicity decrease.

\section{Fenton treatment}

Fenton treatment without $\mathrm{pH}$ regulation was applied to remove the dissolved organic matter in samples $\mathrm{S} 1$ and $\mathrm{S} 2$; two reagent doses $\left(\mathrm{COD} / \mathrm{H}_{2} \mathrm{O}_{2} / \mathrm{Fe}^{2+}{ }_{\text {w/w }} / \mathrm{w}\right.$ of $1 / 1 / 0.2$ and $1 / 2 / 0.4$ ), which proved effective in industrial wastewater treatment (Trapido et al. 2009), were chosen. The results (Fig. 2a) show significant $\mathrm{COD}$ and $\mathrm{BOD}_{7}$ removal (ca. 60-80 and $60 \%$, respectively), while removing well over 


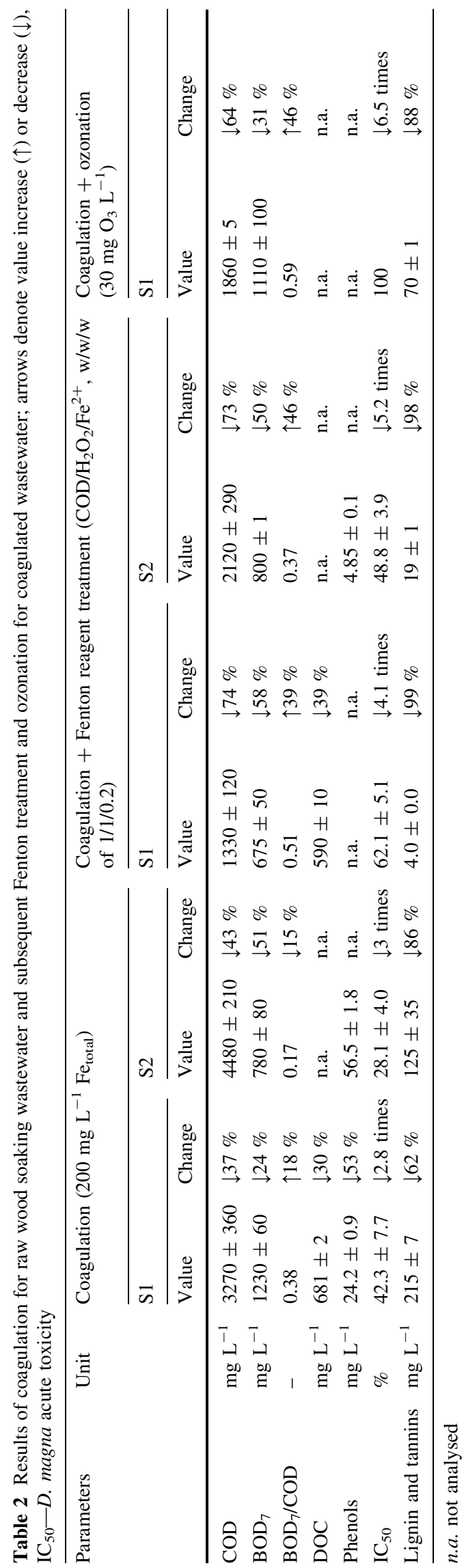

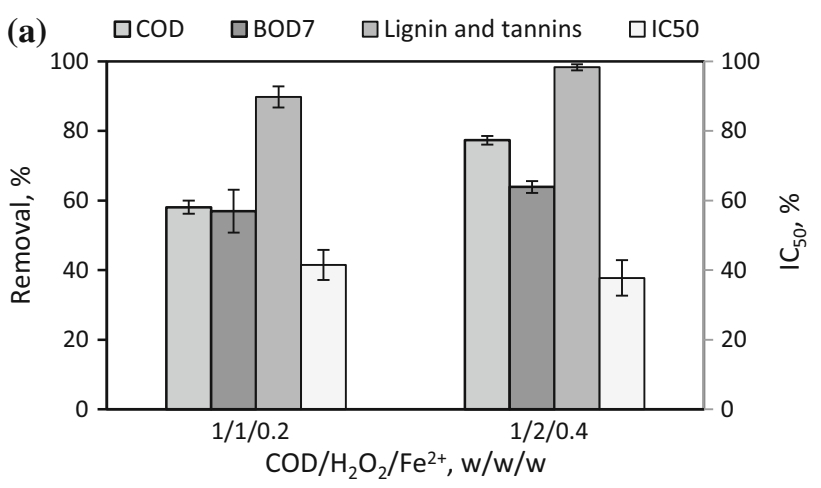

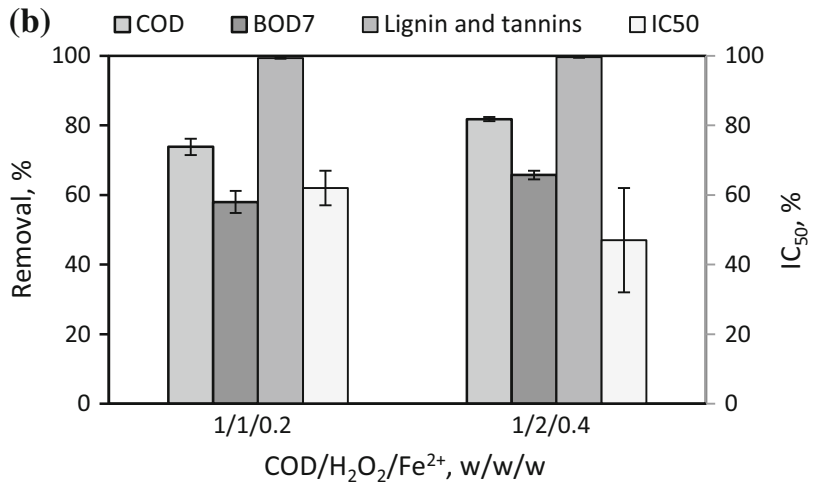

Fig. 2 Results of wood soaking basin wastewater (sample S1) treatment by the Fenton process (a) and a combination of coagulation and the Fenton process (b) expressed in terms of $\mathrm{COD}, \mathrm{BOD}_{7}$ and lignin and tannins removal, and Daphnia magna acute toxicity $\left(\mathrm{IC}_{50}\right)$ decrease (initial value $15.3 \pm 2.2 \%$ )

$90 \%$ of lignin and tannins, and providing almost threefold toxicity decrease at best; the lower reagent dose ratio $\left(\mathrm{COD} / \mathrm{H}_{2} \mathrm{O}_{2} / \mathrm{Fe}^{2+}{ }_{\mathrm{w}} / \mathrm{w} / \mathrm{w}\right.$ of $\left.1 / 1 / 0.2\right)$ provided a somewhat higher toxicity removal.

\section{Coagulation followed by Fenton treatment}

Same doses of Fenton reagent as above were applied to pre-coagulated sample S1. With both reagent doses, Fenton treatment provided comparable results in terms of COD, $\mathrm{BOD}_{7}$ and lignin and tannins removal. At the same time, the lower reagent dose ratio provided a more pronounced decrease in the acute toxicity of the treated sample (see Fig. 2b). When compared to Fenton treatment only, the combination of coagulation and Fenton treatment provided superior results in COD and lignin removal, while the removal of $\mathrm{BOD}_{7}$ was almost identical (Table 2). Indeed, coagulation and Fenton treatment at the lower reagent dose ratio provided results comparable to Fenton process alone conducted with the higher reagent dose ratio; moreover, the consumption of hydrogen peroxide is reduced over three times in the combined process. Coagulation followed by Fenton process removed significant amount of phenols, resulting in $<5 \mathrm{mg} \mathrm{L}^{-1}$ concentration in the effluent. 
According to the inhibition tests, current method completely removed the inhibitory effect.

The oxidative potential of non-catalysed hydrogen peroxide was studied as well. For sample S1, hydrogen peroxide oxidation at a $\mathrm{COD} / \mathrm{H}_{2} \mathrm{O}_{2} \mathrm{w} / \mathrm{w}$ of $1 / 1$ resulted in more than $50 \%$ COD and DOC removal mainly due to the residual iron content $\left(\mathrm{Fe}_{\text {total }}\right.$ of $\left.0.09 \mathrm{~g} / \mathrm{L}\right)$ after coagulation step. However, the addition of iron catalyst to achieve $\mathrm{H}_{2} \mathrm{O}_{2} / \mathrm{Fe}^{2+}$ weight ratio 5:1 considerably (up to $40 \%$, depending on the reagent dose ratio) improved overall efficacy of S1 treatment.

Coagulation and Fenton $\left(\mathrm{COD} / \mathrm{H}_{2} \mathrm{O}_{2} / \mathrm{Fe}^{2+}\right.$ w/w/w of $1 / 1 /$ 0.2 ) treatment effect on biodegradability and concentration of recalcitrant COD was also assessed (Fig. 3). Although the treated wastewater has high fraction of easily biodegradable COD, coagulation followed by Fenton treatment reduced 28 -day biodegradability to $74 \%$. Additionally, compared to raw wastewater, the recalcitrant COD did not decrease. However, coagulation and Fenton treatment removed slowly biodegradable fraction from the wastewater (Fig. 3).

Consequently, the combination of coagulation $\left(200 \mathrm{mg} \mathrm{L}^{-1}\right.$ PIX-322) and Fenton treatment $\left(\mathrm{COD} / \mathrm{H}_{2} \mathrm{O}_{2} / \mathrm{Fe}^{2+}{ }_{\mathrm{w}} / \mathrm{w} / \mathrm{w}\right.$ of $1 / 1 / 0.2$ ) was found to be the most efficient of chemical treatment methods in terms of both performance and reagent consumption reduction. At the same time, there was high concentration of residual COD in the effluent $\left(2120 \mathrm{mg} \mathrm{L}^{-1}\right)$, which makes the combination solely inefficient.

\section{Evaluation of combined Fenton and biological} treatment

\section{Biological treatment with chemical post-treatment (BIO- CHEM)}

As the biodegradability test results for raw wastewater compared to chemical pre-treatment effluent showed higher biodegradability (Fig. 3), it is reasonable to employ

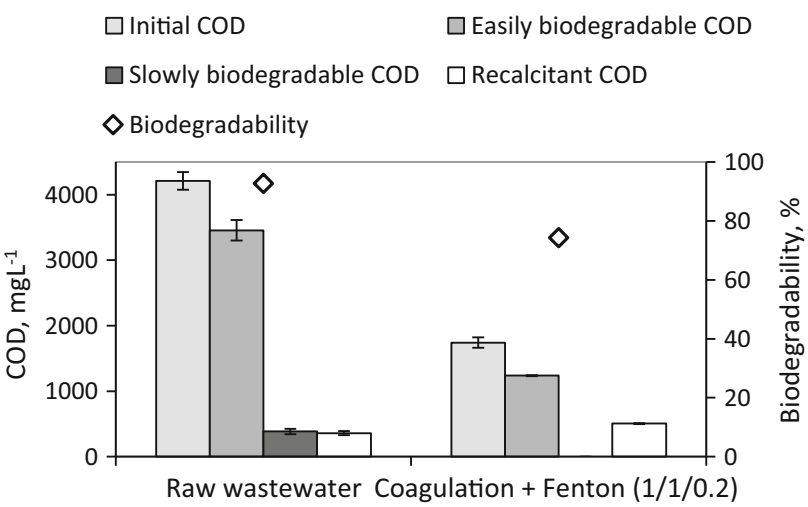

Fig. 3 Biodegradability and COD fractions of raw and treated (coagulation combined with Fenton treatment) hardwood soaking basin wastewater (sample S2) biological pre-treatment in order to remove easily biodegradable organics. At the same time, there would be considerable concentration of recalcitrant $\mathrm{COD}$ in the biological treated effluent, which needs further physicochemical treatment. Among the chemical treatment methods analysed in the previous sections, Fenton treatment was chosen by the authors to be employed. The reasons behind this is the highly efficient performance of the method towards both composite wastewater parameters, such as $\mathrm{COD}$ and $\mathrm{BOD}_{7}$, and individual compounds, such as lignin and tannins (see Table 2), coupled with simplicity of Fenton treatment instrumental set-up (as opposed to, for example, ozonation). As for the set-up simplicity, the possibility to reuse ferric hydroxide sludge, as reported by the authors (Bolobajev et al. 2014), makes the operation potentially even more simple and reliable: besides the absence of ferric hydroxide sludge removal, dewatering and disposal stages, this results also in decreased consumption of fresh iron source.

As the hydroxyl radicals abundantly produced in Fenton's reaction are strong oxidisers reacting with all types of organic pollutants indiscriminately, it is highly important that the biological treatment removes the easily biodegradable fraction beforehand and leaves the recalcitrant fraction of the COD as the sole target for Fenton process. Biological treatment is also cost-efficient compared to physiochemical method (Gotvajn et al. 2009).

In order to eliminate readily biodegradable fraction from the raw wastewater, applying cost-effiective approach, laboratory-scale aerobic biological treatment was carried out (sample S3); the results can be seen in Table 3. Biological pre-treatment removed $78 \%$ of COD and $92 \%$ of $\mathrm{BOD}_{7}$, leaving COD and $\mathrm{BOD}_{7}$ concentrations of 1490 and $300 \mathrm{mg} \mathrm{L}^{-1}$ respectively. Although the raw wastewater has inhibitory effect on activated sludge nitrification rate, $88 \%$ of TN was removed. Additionally, biological pretreatment showed high efficiency in removal of phenols (84\%). Consequently, as the biological pre-treatment has a higher efficiency in COD removal than coagulation combined with ozonation (64\% of COD) or Fenton (74\% of COD), it is reasonable to treat the plywood wastewater biologically as the first step of a combined process both in terms of performance optimisation and the reduction in reagent consumption.

When biologically treated water (sample S3) was subjected to Fenton process with prior $\mathrm{pH}$ adjustment to 3, the overall COD removal increased up to $96-97 \%$ (see Fig. 4). The experiments conducted without prior $\mathrm{pH}$ regulation yielded 5-7 \% lower results. The detailed results of optimal-dose Fenton treatment of the wood soaking basin water after biological stage of the combined process can be seen in Table 3. Thus, the effluent of BIO-CHEM process $(1 / 2 / 0.4)$ has both $\mathrm{COD}$ and $\mathrm{BOD}_{7}$ decreased by 


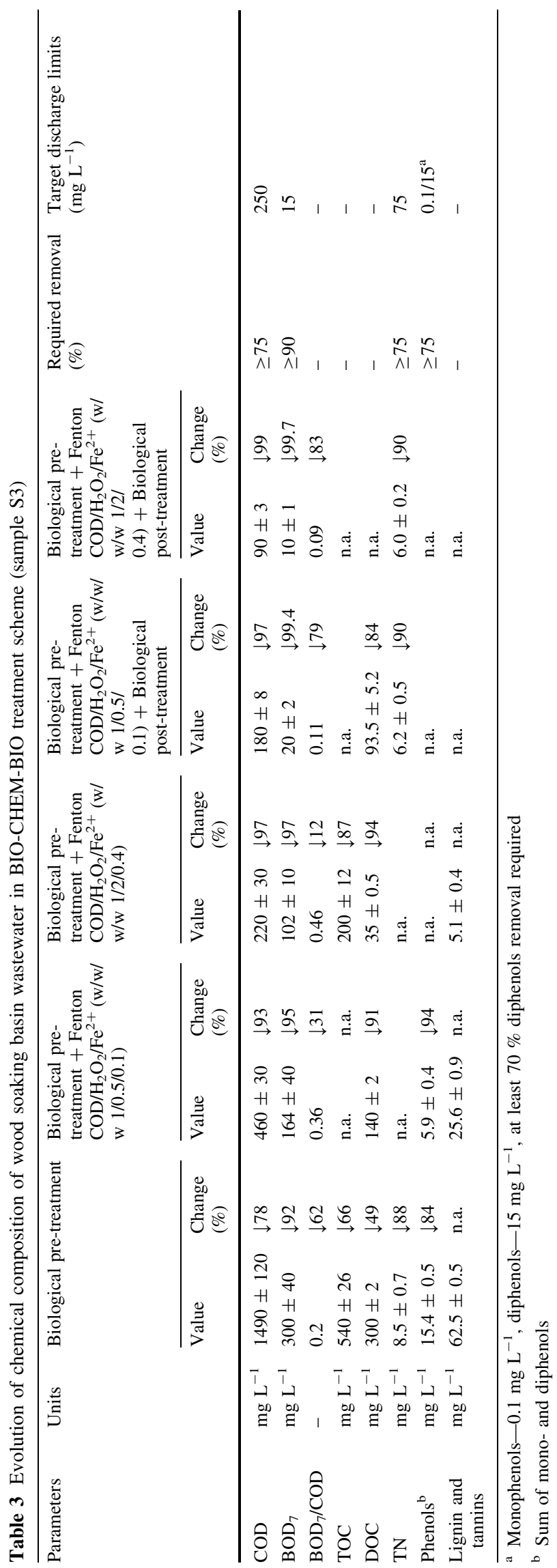

$97 \%$ from the original value, while retaining roughly the same $\mathrm{BOD}_{7}$-to-COD ratio. Estonian legislation in compliance with EU legislation (EEC 1991) for effluents originating from industries, including wood industry, states discharge limits for $\mathrm{COD}$ and $\mathrm{BOD}_{7}$ as 250 and $15 \mathrm{mg} \mathrm{L}^{-1}$, respectively; alternatively, the removal rates of these should be at least 75 and $90 \%$, respectively. For the purpose of achieving target limits simultaneously minimising the consumption of chemicals in the BIO-CHEM process, biologically pre-treated wastewater was subjected to Fenton treatment applying oxidant dose ratio (COD/ $\mathrm{H}_{2} \mathrm{O}_{2} / \mathrm{Fe}^{2+}$, w/w/w) of $1 / 0.5 / 0.1$. Overall removal efficiencies were substantial-93\% for COD and $95 \%$ for $\mathrm{BOD}_{7}$ - but the corresponding $\mathrm{COD}$ and $\mathrm{BOD}_{7}$ values in effluent were 460 and $164 \mathrm{mg} \mathrm{L}^{-1}$, respectively. Considering the discharge limits, Fenton post-treatment with applied dose ratio of $\left(\mathrm{COD} / \mathrm{H}_{2} \mathrm{O}_{2} / \mathrm{Fe}^{2+}\right.$, w/w/w) $1 / 2 / 0.4$ achieved COD target, obtaining $220 \mathrm{mg} \mathrm{L}^{-1}$ of COD for effluent. Contrary to $\mathrm{COD}$ removal, $\mathrm{BOD}_{7}$ concentration in the effluent of BIO-CHEM treatment did not met the discharge limit. Consequently, BIO-CHEM process was not sufficient and wastewater needs further treatment.

\section{Biological pre-treatment with subsequent chemical treatment and biological post-treatment (BIO-CHEM-BIO)}

Before selecting the possible final purification method, biodegradability test was performed in order to assess Fenton-treated wastewater suitability for biological treatment. The results of the test (Fig. 5) suggest that Fenton post-treatment, even at reduced chemical doses, increased the effluent biodegradability, at the same time providing twofold decrease in recalcitrant COD fraction. To assess the higher Fenton reagent dose impact on the biodegradability, Zahn-Wellens test for Fenton post-treated wastewater was performed (Fig. 5). The results indicate that higher ratio $\mathrm{COD} / \mathrm{H}_{2} \mathrm{O}_{2} / \mathrm{Fe}^{2+}(\mathrm{w} / \mathrm{w} / \mathrm{w})$ of $1 / 2 / 0.4$ increases biodegradability $11 \%$, reduces slowly biodegradable fraction $(47 \%)$ and recalcitrant COD (52\%). These observations imply that the wastewater treatment with ratios $\left(\mathrm{COD} / \mathrm{H}_{2} \mathrm{O}_{2} / \mathrm{Fe}^{2+}\right.$, w/w/w) of $1 / 0.5 / 0.1$ and $1 / 2 / 0.4$ could be efficiently combined with further biological treatment, suggesting residual COD to be around 180 and $90 \mathrm{mg} \mathrm{L}^{-1}$, respectively.

To ensure that the final effluent $\mathrm{COD}$ and $\mathrm{BOD}_{7}$ were below discharge limits, biological post-treatment was applied as the third and final step (Table 3). The three-stage treatment with four times lower reagent dose in Fenton process $\left(\mathrm{COD} / \mathrm{H}_{2} \mathrm{O}_{2} / \mathrm{Fe}^{2+}\right.$, w/w/w of $\left.1 / 0.5 / 0.1\right)$ provided overall $\mathrm{COD}$ and $\mathrm{BOD}_{7}$ removal efficiencies 97 and $99.4 \%$, respectively, leaving $180 \mathrm{mg} \mathrm{L}^{-1} \mathrm{COD}$ and $20 \mathrm{mg} \mathrm{L}^{-1}$ $\mathrm{BOD}_{7}$ in the effluent. Although $\mathrm{BOD}_{7}$ value in the effluent is over the threshold value, it is not expected to be a problem in 


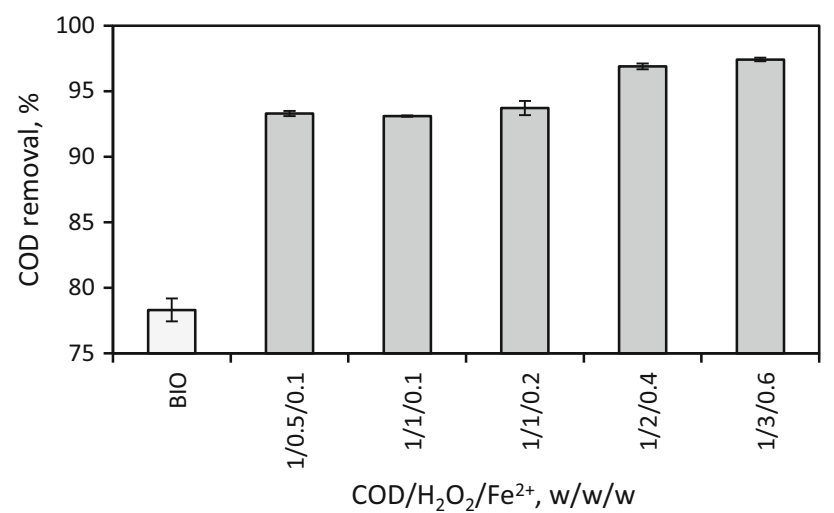

Fig. 4 Results of biologically pre-treated wood soaking basin wastewater treatment by the Fenton process at $\mathrm{pH} 3$ expressed in terms of COD removal (sample S3), compared to the results obtained by biological treatment (BIO)

a full-scale wastewater treatment plant. In laboratory-scale pilot plant, the activated sludge settleability is inferior and suspended solids are transferred into effluent. Therefore, the treatment combination with Fenton dose ratio $\left(\mathrm{COD} / \mathrm{H}_{2} \mathrm{O}_{2} /\right.$ $\mathrm{Fe}^{2+}$, w/w/w) of 1/0.5/0.1 should be sufficient in treating plywood industry wastewater starting from at least pilot scale, which is to be a subject of a separate upcoming publication of the authors. To produce effluent in accordance with municipal wastewater normative, the combined process was carried out with higher reagent dose ratio in chemical treatment stage $\left(\mathrm{COD} / \mathrm{H}_{2} \mathrm{O}_{2} / \mathrm{Fe}^{2+}\right.$, w/w/w of $\left.1 / 2 / 0.4\right)$. The results (Table 3 ) indicate that such combination would ensure obtaining target limits enacted to municipal WWTP effluent (EU 1991). Indeed, the aerobic biological posttreatment was consistent with the preliminary estimates, achieving the predicted effluent COD.

\section{Evaluation of chemicals consumption}

Estimates on the consumption of Fenton reagent chemicals can be seen in Table 4 . The results indicated the perspective of considerable reagents overuse (ca. 3.5 times in the case of Fenton treatment) when applying direct chemical treatment for wastewaters containing relatively high amounts of readily biodegradable organic matter, compared to the combination including the biological pre-treatment, which eliminates that fraction, allowing Fenton treatment (reagent dose ratio of 1/2/0.4 can be considered optimal with the obtained effluent quality results) to degrade the recalcitrant part only (BIO-CHEM process), and finishing it with biological post-treatment. The combination of coagulation and Fenton treatment provides a $10 \%$ increase in Fenton reagent consumption in comparison with the currently optimal BIOCHEM-BIO process; however, the consumption of coagulant and the respective set-up, including dosage pumps, stirrers, clarification, should be also taken into account.

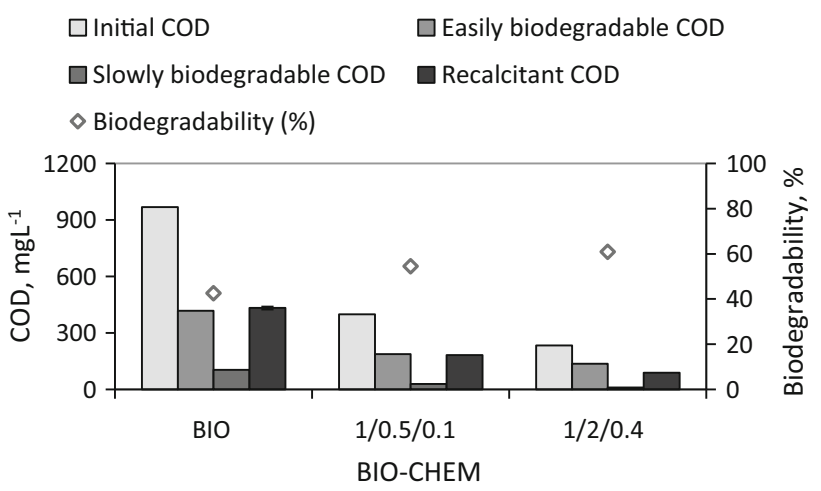

Fig. 5 Changes in wastewater biodegradability in different BIOCHEM treatment schemes (sample S3)

As for the comparison between two doses of Fenton reagent employed in the BIO-CHEM-BIO process, both guarantee the required removal percentage of the investigated primary parameters; however, when it comes to specific target discharge limits, the higher Fenton reagent dose (1/2/0.4) allows fulfilling them as well. While the lower (1/0.5/0.1) Fenton reagent dose-employing BIOCHEM-BIO set-up produces an effluent with $\mathrm{BOD}_{7}$ slightly over the target discharge limit (20 as opposed to $15 \mathrm{mg} \mathrm{L}^{-1}$ ) in laboratory conditions, it is highly likely that under larger-scale applications with better sludge settling, the values of the respective parameters in the effluent should decreased and thus will be in full compliance with the regulations. In that case, a further fivefold reagent consumption decrease from the currently optimal BIOCHEM-BIO process can be achieved.

As for the process operating costs, analysed for the particular local situation, it can be seen that direct physicochemical treatment of the wood soaking basin wastewater is not a very feasible option, although a substantial cost reduction can be achieved when using coagulation as the first stage of chemical treatment. Biological treatment (BIO), being the cheapest of the alternatives analysed, cannot provide an effluent meeting the target discharge limits, even though the removal percentage is in accordance with the legislation; the same stands for a combination of biological pre-treatment and chemical post-treatment (BIO-CHEM). As for the BIO-CHEM-BIO process, its costs, even though higher than that of biotreatment, are significantly lower than those of chemical treatment; at the same time, it provides effluent completely corresponding to the legislation. Possible reuse of ferric hydroxide sludge may further significantly reduce the operating cost of $\mathrm{BIO}-\mathrm{CHEM}-\mathrm{BIO}$, as the costs of ferric sulphate comprise around $25 \%$ of the total reagent cost. The possibility of applying the combined process with lower reagent dose ratio, when coupled with ferric hydroxide sludge reuse, may provide even lower treatment costs than the already competitive 2.30 eur $\mathrm{m}^{-3}$. 
Table 4 Chemicals consumption in different processes applied for the wood soaking basin wastewater treatment

\begin{tabular}{|c|c|c|c|c|c|c|c|}
\hline Process & Sample & $\begin{array}{l}\text { Energy } \\
\text { consumption } \\
\left(\mathrm{kW} \mathrm{h} \mathrm{m}^{-3}\right)\end{array}$ & $\begin{array}{l}\text { PIX-322 } \\
\left(\mathrm{kg} \mathrm{m}^{-3}\right)\end{array}$ & $\begin{array}{l}\mathrm{H}_{2} \mathrm{O}_{2} \\
(50 \% \\
\left(\mathrm{kg} \mathrm{m}^{-3}\right)\end{array}$ & $\begin{array}{l}\mathrm{FeSO}_{4} \\
\cdot 7 \mathrm{H}_{2} \mathrm{O} \\
\left(\mathrm{kg} \mathrm{m}^{-3}\right)\end{array}$ & $\begin{array}{l}\text { Effluent correspondence to } \\
\text { legislation (removal \%/effluent } \\
\text { concentrations) })^{\mathrm{a}}\end{array}$ & $\begin{array}{l}\text { Treatment } \\
\text { cost } \\
\left(\text { eur } \mathrm{m}^{-3}\right)\end{array}$ \\
\hline \multirow[t]{2}{*}{ Fenton treatment $(1 / 2 / 0.4)$} & S1 & $\mathrm{n} / \mathrm{a}^{\mathrm{b}}$ & - & 20.6 & 10.3 & $-1-$ & 24.19 \\
\hline & S2 & & & 31.4 & 15.6 & $-1-$ & 36.91 \\
\hline $\begin{array}{l}\text { Coagulation }\left(200 \mathrm{mg} \mathrm{L}^{-1}\right. \\
\left.\mathrm{Fe}_{\text {total }}\right)+ \text { ozonation } \\
\left(30 \mathrm{mg} \mathrm{L}^{-1} \mathrm{O}_{3}\right)\end{array}$ & S1 & 60.0 & 1.6 & - & - & $-1-$ & 3.99 \\
\hline Coagulation $\left(200 \mathrm{mg} \mathrm{L}^{-1}\right.$ & S1 & $\mathrm{n} / \mathrm{a}^{\mathrm{b}}$ & 1.6 & 6.5 & 3.3 & $-1-$ & 8.16 \\
\hline $\begin{array}{l}\left.\mathrm{Fe}_{\text {total }}\right)+ \text { Fenton treatment } \\
(1 / 1 / 0.2)\end{array}$ & S2 & & & 9.0 & 4.5 & $-1-$ & 10.96 \\
\hline $\mathrm{BIO}$ & S3 & 6.0 & - & - & - & $+1-$ & 0.53 \\
\hline BIO-CHEM (1/2/0.4) & S3 & & - & 6.0 & 3.0 & $+/-$ & 7.53 \\
\hline BIO-CHEM $(1 / 0.5 / 0.1)$ & S3 & & - & 1.5 & 0.7 & $+/-$ & 2.28 \\
\hline BIO-CHEM-BIO (1/2/0.4) & S3 & 6.2 & - & 6.0 & 3.0 & $+/+$ & 7.54 \\
\hline BIO-CHEM-BIO (1/0.5/0.1) & S3 & & - & 1.5 & 0.7 & $+/ \pm^{c}$ & 2.30 \\
\hline
\end{tabular}

a See Tables 2 and 3 for more information

b Not analysed (see "Evaluation of reagent consumption" section)

c See "Evaluation of chemicals consumption" section in discussion

\section{Conclusion}

In this research, the typical hardwood soaking basin wastewater, containing a high load of wood and bark-originating water extractive material, was subjected to combined treatment processes consisting of physicochemical and biological stages. As the preliminary biodegradability analyses suggested, the raw wastewater had high biodegradability (93\%); therefore; biological treatment was eventually chosen as the first stage of the combined process. Biological pre-treatment removed $\mathrm{COD}, \mathrm{BOD}_{7}$, phenols and $\mathrm{TN}$ to the extent of 78, 92, 84 and $88 \%$, respectively; although the specified removal rates were in accordance with the directive 91/271 EEC, the residual COD, $\mathrm{BOD}_{7}$ and phenols concentrations were well above the target discharge limits specified there. Since the plywood industry wastewater contained a significant amount of recalcitrant COD, Fenton treatment with dose ratios $\left(\mathrm{COD} / \mathrm{H}_{2} \mathrm{O}_{2} / \mathrm{Fe}^{2+}\right.$, w/w/w) of $1 / 0.5 / 0.1$ and $1 / 2 / 0.4$ was applied after biological pre-treatment, which resulted in up to $97 \%$ overall removal of COD and $\mathrm{BOD}_{7}$. Additionally, Fenton treatment increased the biodegradability, which enabled to employ biological posttreatment as a final purification. Consequently, the optimal process for the wood soaking basin wastewater treatment is the BIO-CHEM-BIO process applying Fenton treatment at the dose ratio $\left(\mathrm{COD} / \mathrm{H}_{2} \mathrm{O}_{2} / \mathrm{Fe}^{2+}\right.$, w/w/w) of $1 / 2 / 0.4$ at the chemical treatment stage, producing effluent meeting the target discharge limits set by the EEC Directive 91/271 for industrial and municipal wastewater as well. To conclude, this study presents a novel approach to the wood soaking basin wastewater treatment, producing a cost-effective and readily applicable combined treatment process, efficient in terms of both results and chemical cost reduction, and at the same time successfully meeting the required target discharge limits.

Acknowledgments The authors would like to express their gratitude to the financial support of the European Union through the European Regional Development Fund project CHEMBIO (code 3.2.0802.11-0043) and the institutional research funding IUT1-7 and IUT20-16 of the Estonian Ministry of Education and Research. The authors would also like to thank Nadežda Vidinjova M.Sc. for her technical assistance.

\section{References}

Algol Chemicals OÜ (2014) http://www.algol.ee/

APHA (2012) Standard Methods for the Examination of Water and Wastewater, 22nd edn. American Water Works Association, Water Environment Federation, Washington

Bolobajev J, Kattel E, Viisimaa M, Goi A, Trapido M, Tenno T, Dulova N (2014) Reuse of ferric sludge as an iron source for the Fenton-based process in wastewater treatment. Chem Eng J 255:8-13

Dulova N, Trapido M (2011) Application of Fenton's reaction for food-processing wastewater treatment. J AOTs 14:9-16

ECS (1997) Standard ICS 13.060.30. Water analysis: Guidelines for the determination of total organic carbon (TOC) and dissolved organic carbon (DOC). European Committee for Standardization, Brussels

EEC (1991) Council Directive 91/271/EEC. European Econimic Community, Brussels

AS Eesti Energia (2014) Price list for electricity packages 2014. https://www.energia.ee/en/hinnakiri

Fernández FJ, Castro MC, Rodrigo MA, Cañizares P (2011) Reduction of aeration costs by tuning a multi-set point on/off controller: a case study. Control Eng Pract 19:1231-1237

Fernández FG, de Palacios P, Esteban LG, Garcia-Iruela A, Rodrigo BG, Menasalvas E (2012) Prediction of MOR and MOE of structural plywood board using an artificial neural network and comparison with a multivariate regression model. Compos B 43:3528-3533 
Gotvajn AŽ, Tišler T, Zagorc-Končan J (2009) Comparison of different treatment strategies for industrial landfill leachate. J Hazard Mater 162:1446-1456

Han W, Luo L, Zhang S (2012) Adsorption of bisphenol A on lignin: effects of solution chemistry. Int J Environ Sci Technol 9:543-548

ISO (1984) Standard ISO 7150-1:1984. Water quality-determination of ammonium-part 1: manual spectrometric method. International Organization for Standardization, Geneva

ISO (1988) Standard ISO 7890-3:1988. Water quality-determination of nitrate-part 3: spectrometric method using sulfosalicylic acid. International Organization for Standardization, Geneva

ISO (2003) Standard EN ISO 11905-1:2003. Water quality-determination of nitrogen-part 1: method using oxidative digestion with peroxodisulfate. International Organization for Standardization, Geneva

ISO (2006) Standard ISO 9509:2006. Water quality-toxicity test for assessing the inhibition of nitrification of activated sludge microorganisms. International Organization for Standardization, Geneva

ISO (2007) Standard ISO 8192:2007. Water quality-test for inhibition of oxygen consumption by activated sludge for carbonaceous and ammonium oxidation. International Organization for Standardization, Geneva

ISO (2012) International standard ISO 6341:2012, Water qualitydetermination of the inhibition of the mobility of Daphnia magna Straus (Cladocera, Crustacea) - acute toxicity test. International Organization for Standardization, Geneva

Jokela P, Keskitalo P (1999) Plywood mill water system closure by dissolved air flotation treatment. Water Sci Technol 40:33-41

Kemira (2014) http://www.kemira.com

Kindsigo M, Kallas J (2009) Wet oxidation of debarking water: changes in lignin content and biodegradability. Environ Chem Lett 7:121-126

Klauson D, Kivi A, Kattel E, Klein K, Viisimaa M, Bolobajev J, Velling S, Goi A, Tenno T, Trapido M (2014) Combined processes for wastewater purification: treatment of a typical landfill leachate with a combination of chemical and biological oxidation processes. J Chem Technol Biotechnol. doi:10.1002/ jctb. 4484

Kostamo A, Kukkonen JVK (2003) Removal of resin acids and sterols from pulp mill effluents by activated sludge treatment. Water Res 37:2813-2820

Krichevskaya M, Klauson D, Portjanskaja E, Preis S (2011) The cost evaluation of advanced oxidation processes in laboratory and pilot-scale experiments. Ozone Sci Eng 33:211-223

Kulik N, Trapido M, Goi A, Veressinina Y, Munter R (2008) Combined chemical treatment of pharmaceutical effluents from medical ointment production. Chemosphere 70:1525-1531

Lehtinen K-J, Mattsson K, Tana J, Engström C, Lerche O, Hemming J (1999) Effects of wood-related sterols on the reproduction, egg survival, and offspring of brown trout (Salmo trutta lacustris L.). Ecotoxicol Environ Saf 42:40-49

Leiviska T, Sarpola A, Tanskanen J (2012) Removal of lipophilic extractives from debarking wastewater by adsorption on kaolin or enhanced coagulation with chitosan and kaolin. Appl Clay Sci 61:22-28

Leiviskä T, Nurmesniemi H, Pöykiö R, Rämö J, Kuokkanen T, Pellinen J (2008) Effect of biological wastewater treatment on the molecular weight distribution of soluble organic compounds and on the reduction of BOD, COD and $\mathrm{P}$ in pulp and paper mill effluent. Water Res 42:3952-3960

Leiviskä T, Rämö J, Nurmesniemi H, Pöykiö R, Kuokkanen T (2009) Size fractionation of wood extractives, lignin and trace elements in pulp and paper mill wastewater before and after biological treatment. Water Res 43:3199-3206

Libralato G, Avezzu F, Volpi Ghirardini A (2011) Lignin and tannin toxicity to Phaeodactylum tricornutum (Bohlin). J Hazard Mater 194:435-439

Liu C, Li S, Zhang F (2011) The oxygen transfer efficiency and economic cost analysis of aeration system in municipal wastewater treatment plant. Energy Proc 5:2437-2443

Lotito AM, De Sanctis M, Rossetti S, Lopez A, Di Iaconi C (2014) On-site treatment of textile yarn dyeing effluents using an integrated biological-chemical oxidation process. Int $\mathrm{J}$ Environ Sci Technol 11:623-632

Malato S, Jn Blanco, Maldonado MI, Oller I, Gernjak W, PérezEstrada L (2007) Coupling solar photo-Fenton and biotreatment at industrial scale: main results of a demonstration plant. J Hazard Mater 146:440-446

Mantzavinos D, Psillakis E (2004) Enhancement of biodegradability of industrial wastewaters by chemical oxidation pre-treatment. J Chem Technol Biotechnol 79:431-454

Munoz M, Pliego G, de Pedro ZM, Casas JA, Rodriguez JJ (2014) Application of intensified Fenton oxidation to the treatment of sawmill wastewater. Chemosphere 109:34-41

Munter R, Trapido M, Veressinina Y, Goi A (2006) Cost effectiveness of ozonation and AOPs for aromatic compound removal from water: a preliminary study. Ozone Sci Eng 28:287-293

Papa M, Pedrazzani R, Bertanza G (2013) How green are environmental technologies? a new approach for a global evaluation: the case of WWTP effluents ozonation. Water Res 47:3679-3687

Pophali GR, Kaul SN, Mathur S (2003) Influence of hydraulic shock loads and TDS on the performance of large-scale CETPs treating textile effluents in India. Water Res 37:353-361

Portjanskaja E, Stepanova K, Klauson D, Preis S (2009) The influence of titanium dioxide modifications on photocatalytic oxidation of lignin and humic acids. Catal Today 144:26-30

Reemtsma T, Putschew A, Jekel M (1999) Industrial wastewater analysis: a toxicity-directed approach. Waste Manag 19:181-188

Ren S (2004) Assessing wastewater toxicity to activated sludge: recent research and developments. Environ Int 30:1151-1164

Seetha N, Bhargava R, Kumar P (2010) Effect of organic shock loads on a two-stage activated sludge-biofilm reactor. Bioresour Technol 101:3060-3066

Singh A, Prasad SM (2015) Remediation of heavy metal contaminated ecosystem: an overview on technology advancement. Int $\mathbf{J}$ Environ Sci Technol 12:353-366

Stahlschmidt-Allner P, Allner B, Römbke J, Knacker T (1997) Endocrine disrupters in the aquatic environment. Environ Sci Pollut Res 4:155-162

Trapido M, Kulik N, Goi A, Veressinina Y, Munter R (2009) Fenton treatment efficacy for the purification of different kinds of wastewater. Water Sci Technol 60:1795-1801

Villano M, Scardala S, Aulenta F, Majone M (2013) Carbon and nitrogen removal and enhanced methane production in a microbial electrolysis cell. Bioresour Technol 130:366-371

Vlyssides A, Barampouti EM, Mai S, Vlyssides A (2008) Application of Fenton's reagent on wastewater from a wood processing industry. Environ Eng Sci 25:327-331

Wang JL, Xu LJ (2012) Advanced oxidation processes for wastewater treatment: formation of hydroxyl radical and application. Crit Rev Environ Sci Technol 42:251-325

Wang K, Wang S, Zhu R, Miao L, Peng Y (2013) Advanced nitrogen removal from landfill leachate without addition of external carbon using a novel system coupling ASBR and modified SBR. Bioresour Technol 134:212-218 